\title{
Using Public Private Partnerships to Accelerate Student Success
}

\author{
Vicki L. Golich, Sandra Haynes, and Steve Kreidler
}

\begin{abstract}
Metropolitan State University of Denver (MSU Denver) has used various ways to craft curriculum that directly meets employers' and students' needs in key economic drivers in the State of Colorado. Moving beyond the standard industry advisory councils used in many, especially professional programs, the institution has consulted with industry leaders prior to building facilities and developing curriculum to ensure industry needs are met. As MSU Denver faculty collaborated with their industry partners, they worked to embed both content and skills throughout the curriculum to ensure alumni were prepared for this $21^{\text {st }}$ Century workplace. Additionally, MSU Denver has honored past experience and on the job training of employers and employees in a way that many four-year institutions have resisted.
\end{abstract}

Keywords: workforce; curriculum; public/private partnerships

\section{Introduction}

Over 80 years ago, John Dewey (1933, p. 35) challenged the academy to think seriously about student learning versus faculty teaching: "[T]here are teachers who think they have done a good day's teaching irrespective of what pupils have learned." Ever since, the quest was on to try to understand how students learn, how teachers know what they have learned, and what instructors need them to learn. Research on pedagogy, assessment, and curriculum development now abounds.

Pedagogy

A critical transition in higher education pedagogy came with the recognition that teaching as the "sage on the stage" was less effective than facilitating learning as a "guide on the side," an idea popularized by King (1993; see also Stice, 1987). Work in the classroom shifted from a facultycentered to a student-centered approach, with the focus on student learning rather than faculty teaching. Faculty roles and responsibilities have been evolving ever since (Fabry et. al., 1997; Harris and Bell, 1990). A key element in this transition was to move to active learning strategies designed to engage students in their own discovery of knowledge, as they are required to learn by doing (Boehrer, 1990-91; Chickering \& Gamson, 1987; Ewell \& Jones, 1991; McKeachie, et. a., 1986; Pascarella \& Terrenzini, 1991; Umbach \& Wawrzynski, 2005). Indeed, "Fifteen years of neuroscience, biology, and cognitive psychology research findings on how humans learn offer this powerful and singular conclusion: 'It is the one who does the work who does the learning'" (Doyle, 2008 quoted in Zakrajsek \& Doyle, 2012, p. 7).

According to Mezirow (1991), learning does not occur without the creation of meaning. This constructivist theory called transformative learning holds that learning occurs via the learner's 
interpretation and reinterpretation of their experience. Instrumental learning occurs through solving problems and completing tasks and communicative learning occurs when the student can express what they have learned as well as how it has shaped their feelings and desires (Mezirow, 1991). Transformative learning builds on the work of Carl Rogers (1969) who posited that learning is meaningless without experience. Cognitive understanding is inadequate without experience (e.g., one can understand the process of surgery in great depth while at the same time being loath to allow a surgeon without experience to operate.)

Faculty and researchers seeking to improve student learning quickly realized and systematically discovered that students benefited greatly from frequent feedback on their performance, as well as frequent faculty-student interactions (Bridging the Gap, 2015; Busteed, 2015; Chickering \& Gamson, 1987; Ewell \& Jones, 1991). Metropolitan State University of Denver (MSU Denver) faculty engage their students in working collaboratively to solve a problem, create/innovate a product, or design a strategy for real world applications. For example, Dr. Aaron Brown from Mechanical Engineering Technology and his students worked with Revision International on a community development project in the Westwood neighborhood of Denver where the average household income level is \$18,000 a year. Dr. Brown and 12 students designed and built solar heaters constructed from soda cans, two-by-four lumber, plywood, and computer fans for a total cost of about $\$ 30$. These units saved about \$25 a month on heating bills, a huge savings for families in that income bracket. They installed five demonstration units in Westwood then held a workshop to teach the community how to build their own. Dr. Brown has been approached by the governor's office about statewide implementation and also by the U.S. Institute of Peace, part of the U.S. State Department, for international implementation. Additionally, Aviation and Aerospace students competed with universities all over the world in the Analytical Graphics Inc. (AGI) University Grant competition. Our students, under the supervision of Professor Jose Lopez, used AGI's Satellite Tool Kit for Archaeoastronomy to visualize and analyze ancient monuments' astronomical alignments. Their effort, the first time anyone has ever used STK for this purpose, won them honorable mention in this worldwide competition. This learn-by-doing approach to pedagogy has been successfully graduated students into lucrative careers in local and national high demand fields.

\section{Assessment}

The assessment of learning underwent a revolution in the 1980s and 1990s when regional accrediting agencies started to focus on learning outcomes (e.g., what did students learn and how does one know that) versus learning inputs (e.g., quality of library holdings or faculty credentials). Institutions of higher education realized that they must demonstrate students are graduating with both content knowledge and the skills needed to be successful in the workplace. Harris and Bell (1990) were among the first to call attention to the need for assessment to be "organized with the learners as the main audience for the results" (p. 94). With an emphasis on students as learners, faculty require assessment tools that will help them know when students have not fully understood key concepts or content. Then faculty can work to ensure that students are integrating, synthesizing and constructing their knowledge "in ways consistent with the discipline and the professional pathways on which they [have] embarked” (Meyers and Nulty, 2009, p. 565.) 
Tom Angelo and Patricia Cross (1993), whose work relates closely to transformative learning, inspired a new and effective approach to assessment, through their development and adaptation of classroom assessment techniques. This approach helped professors "obtain useful feedback on what, how much, and how well their students are learning," as a result, faculty can refocus their teaching efforts to increase the effectiveness of student learning (Angelo \& Cross, 1993, p. 3). At MSU Denver, all degree programs have some kind of culminating senior experience or capstone course-typically grounded in a "real world" experience or issue-that enables faculty to assess what students have learned, both in the disciplinary content and about how to work with others to solve problems.

\section{Curriculum Development}

As with pedagogy and assessment, curriculum development is best done intentionally, with a focus on how to engage students purposefully in their learning. A substantial body of research demonstrates that students learn best when they are introduced to a topic or concept; use that information by participating in a variety of activities; and, then, apply their learning to a real world issue related to their interests (see, e.g., Asiala, et. al., 1997; Jankowski, 2016; Meyers \& Nulty, 2009; Wiggins \& McTighe, 2005). The Association of American Colleges and Universities identified eight high impact practices that faculty should consider as they create curriculum. These include first-year seminars and experiences, common intellectual experiences, learning communities, writing-intensive courses, collaborative assignments and projects, undergraduate research, diversity/global learning, service learning/community-based learning, internships, capstone courses and projects (AAC\&U, 2017; Jankowski, et., al., 2009; Kuh, 2008).

Faculty create the most relevant and engaging curriculum when they do three things: (a) Consider the endgame: (b) determine what they want their students to know and be able to do once they have completed the curriculum; and (c) scaffold the needed content, to build sequenced courses. This is so that content knowledge increases over time and integrates the intellectual and twenty-first century "soft skills" so desperately needed in the workforce throughout the curriculum.

Consider the endgame. Consult with those who know what is needful, that is, the potential employer(s). Given that curriculum is the purview of faculty, iterative conversations between faculty and industry members led by faculty are vital to the creation of a workable and sustainable curriculum for both parties. Topics of conversation need to include what students will need to know and be able to do once they graduate with a degree in this program. Then faculty can begin thinking about what kind of course sequencing makes sense (and is feasible), and when to encourage students to participate in internships or service learning activities.

Scaffold the needed content. As faculty develop curriculum, they need to pay attention to how they build content and skills knowledge on work completed in previous courses, and how courses prepare students for future learning (see Figure 1). 


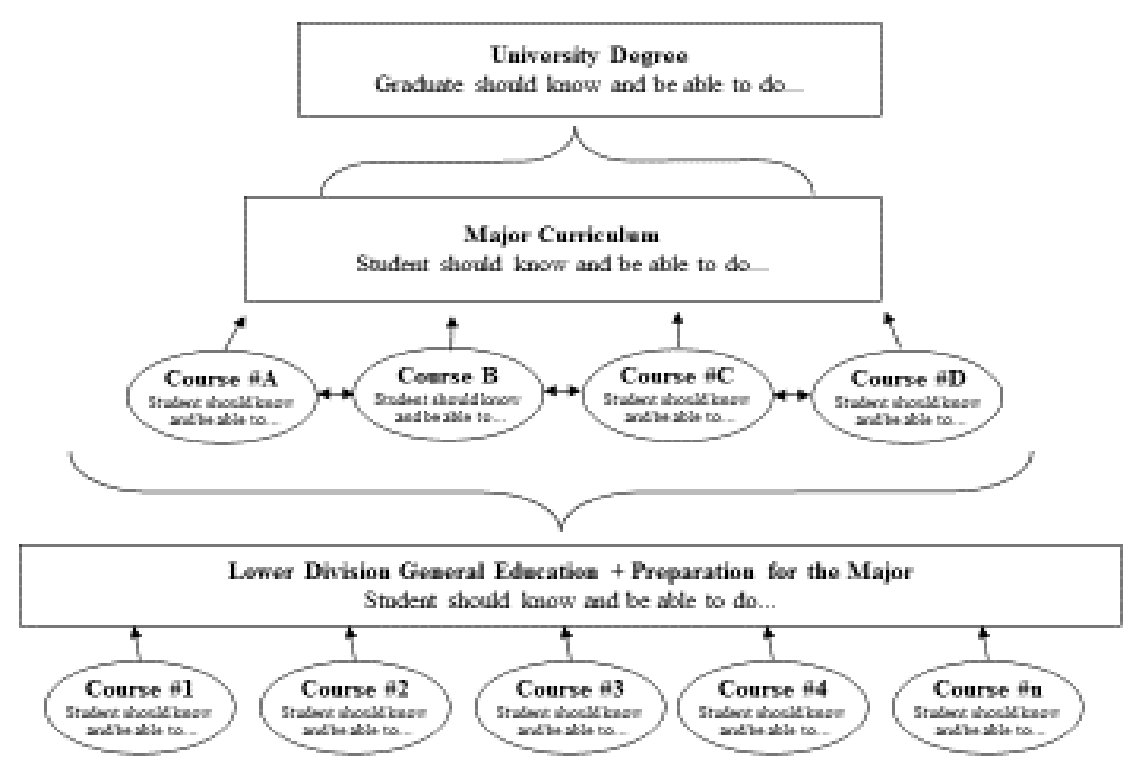

Figure 1. Learning Outcomes Hierarchy Adapted from Golich, 2000, p. 17.

Integrative learning. Once again, intentionality is critical here. Knowledge and skills “...must be developed in, and then applied across, multiple contexts - in different courses, in a variety of disciplines, using a range of modalities” (Newman et al., 2014). Faculty must work to develop instructional materials that foster the active student participation in learning “...guided by knowledge of what students know and can do, rather than by assumptions about what they should know and should be able to do” (McDermott \& Shaffer, 1992, p. 1002). This is the essence of transformative learning: active problem-solving on meaningful tasks. The goal is to ensure that students understand the relevance of course content to their degree program and that they are learning those $21^{\text {st }}$ century soft skills along the way in every course-and, ideally, through co- and extra-curricular activities as well.

New curriculum and program development. MSU Denver has developed systems to align new program, degree, and curriculum development to align closely with workplace demand and experiential learning (see MSU Denver Graduate Program Approval Process, 2017). Recent program growth in hospitality, brewing, aerospace, and advanced manufacturing have been developed through intensive review of expected job growth and gap analysis of supply of qualified employees in our primary service market. The use of State of Colorado documentation (Colorado Workforce Development Council, 2016). 


\section{Application of Theory}

MSU Denver has used the practices described above to create curriculum that directly meets employers' and students' needs in key economic drivers in the State of Colorado and the country. Many MSU Denver academic departments use industry advisory councils to ensure their curriculum is up-to-date and to meet accreditation standards, particularly in its professional programs. To develop new curricula, faculty have worked iteratively with industry leaders prior to building facilities and publishing catalog copy - to ensure industry needs are met. In each case, these conversations have confirmed the need for "T-shaped professionals" in the workforce - people who can solve increasingly complex problems in various work environments (AAC\&U, 2007; Bajada \& Trayler, 2013; Eisenbach et. al., 1998). Employers need to hire people who have both deep knowledge in content and discipline (the vertical part of the T) and the ability to operate effectively across disciplinary boundaries with critical skills such as communication, teamwork, critical thinking, problem solving, leadership, empathy, cultural awareness, creativity and innovation: the horizontal stroke of the T (What is the "T"?, 2014). As MSU Denver faculty collaborated with their industry partners, they worked to embed both content and skills throughout the curriculum, to ensure alumni were prepared for this $21^{\text {st }}$ Century workplace.

Additionally, MSU Denver honors work experience and on-the-job training of employers and employees in a way that many four-year institutions do not. The institution provides credit for prior learning via a portfolio review process that grants academic credit for field courses. Military block credit transfer is allowed through the American Council on Education (ACE) Military Guide recommendations for formal courses and occupations offered by all branches of the military. Currently, MSU Denver is working to accept apprenticeship and journeyman credentials for academic credit.

\section{Integration of Public Private Partnerships (P3's) to Enhance Student Learning Outcomes}

While the use of P3's has become commonplace within higher education in relation to infrastructure and capital facilities, which have dedicated revenue streams (Bernstein, 2016), it is rare to find these partnerships used to create or advance student learning opportunities as the most important reason to create said partnership. MSU Denver has expanded the concept of P3's primarily to drive program development rather than as a revenue source or replacement, though some projects do contain the positive aspects of new facility development as an outcome. This occurs by-the university working with P3 experts in the field to deliver curriculum in an alternative format for current students and those already working in their respective fields. Below are examples of these endeavors.

Hotel and Hospitality Learning Center

A crowning jewel of the Auraria Campus and MSU Denver is the SpringHill Suites by Marriott and its accompanying Hospitality Learning Center (HLC). MSU Denver developed the facility to meet employers' needs for a well-educated workforce in the number one economic cluster in the State, hospitality. The facility is a public-private partnership, built with industry input and in conjunction with Sage Hospitality, a major hospitality development and management company 
headquartered in downtown Denver. The institution's interactions with Sage and other major hospitality firms such as Stonebridge Companies, revealed the need for operations talent in the industry, from front-desk personnel to kitchen managers to general hotel managers. All agreed that experiential learning, coupled with theory, was the best way to educate this type of future employee. A once-small major has now doubled in size, and the curriculum has morphed from a single major with concentrations into four distinct majors. In this case, the curriculum needs, as described by hospitality industry partners, reframed our program and the hotel's operational net income has paid for over 30,000 square feet of new learning facilities attached to the hotel itself.

\section{Brew Pub and Brewing Operations}

Building on the success of the Hotel and HLC, Tivoli Brewing approached MSU Denver to help create a curriculum for students interested in Brew Pub and Brewing Operations, a growing market in Colorado and nationally. The owners' vision was not simply for another brewpub, but a pub that would participate in helping the industry thrive, by providing well-educated owners and staff to the brewing and pub industries. As a result, Tivoli Brewing Company now operates a full brewpub operation on campus where MSU Denver students serve as brew masters for the company. Their learning spaces are co-located with the brewpub itself, for a fully integrated experiential academic program.

Advanced Manufacturing Sciences Institute

In answer to President Barack Obama administration's call to revive the manufacturing industry in the United States, MSU Denver set out to determine what the manufacturing workforce needed. Manufacturing has changed dramatically in the past decades and the talent needed has likewise changed. Aerospace in the second leading economic driver in the State of Colorado and manufacturing is the largest sector in this industry. MSU Denver's administration identified the top aerospace manufacturers in the State and invited them to a brainstorming session prior to the development of any curriculum for an advanced manufacturing program.

These conversations revealed that a broad-based, interdisciplinary, T-shaped curriculum was necessary to meet the needs of a changing workforce. Engineering skills were only part of the equation. Management, computer, and design skills were also important, as were "soft-skills," such as critical thinking, communication, computational reasoning, and teamwork. To meet these needs, MSU Denver created the Advanced Manufacturing Sciences Institute (AMSI) to promote cross-disciplinary collaboration and a curriculum that requires students take courses in a wide array of subjects as well as specialize in a specific area.

This new vision for advanced manufacturing led to the need for a new dedicated facility. Due primarily to the industry/faculty cooperation in creating a leading-edge curriculum that included 22 entirely new courses, the State of Colorado invested \$20 million to assist in the construction of a \$50 million Aerospace and Engineering Sciences Building. Industry partners have contributed to this facility, state-of-the-art technology and equipment has been donated, and four firms have signed leases in the facility to increase their interaction with our faculty and students. 


\section{Construction Project Management}

Once again, success begets success. Industry approached MSU Denver asking for an expansion of the manufacturing curriculum to include trades that often begin with apprenticeships rather than formal higher education. It is often in a company's best interest to promote from within when looking for management talent but the type of education needed for these positions is often lacking. Most trades have rigorous apprenticeship programs that lead to journeyman's credentials and workers do not seek higher education to move beyond their trade. Upon examining Switzerland's model of combining work, apprenticeships, and higher education, the institution created a pathway for journeymen to matriculate into the institution with 30 credit hours granted for apprenticeship and journeyman credentials. This valuing of past experience makes it possible for trades people to gain the education needed to advance in their industry without "starting over."

\section{Conclusion}

Transformative learning takes many forms and begins with excellence in pedagogy. Active learning techniques, conveying relevancy, and assessing outcomes are critical to effective and lasting knowledge and skills. At MSU Denver, such pedagogy starts with the end in mind and moves backwards to ensure curriculum infused with the knowledge and skills students and employers need to be effective in the rapidly changing $21^{\text {st }}$ Century workplace. Conversations with industry partners all indicate that specific skills are indeed necessary but it is what learned while practicing that is most important to for the current and a largely unknown future job market: teamwork, communication, problem solving, leadership, and critical thinking. 


\section{References}

Angelo, T.A., \& Cross, K.P. (1993). Classroom assessment techniques: A handbook for college teachers, $2^{\text {nd }}$ ed. San Francisco, CA: Jossey-Bass.

Asiala, M., Brown, A., DeVries, D.J., Dubinsky, E., Mathews, D., \& Thomas, I. (1994). A framework for research and curriculum development in undergraduate mathematics education. Retrieved from

http://citeseerx.ist.psu.edu/viewdoc/download?doi=10.1.1.47.8763\&rep=rep1\&type=pdf.

Association of American Colleges \& Universities. (2017). High-impact educational practices. Retrieved from https://www.aacu.org/sites/defautl/files/files/LEAP/HIP_tables.pdf.

Association of American Colleges \& Universities. (2017). College learning for the new global century. A report from the National Leadership Council for Liberal Education \& America's Promise. Retrieved from https://www.aacu.org/sites/default/files/files/LEAP/GlobalCentury_final.pdf.

Bajada, C., \& Trayler, R. (2013). Interdisciplinary business education: Curriculum through collaboration. Education + Training, 55(4/5), 385-402. https://doi.org/10.1108/ET-07-20140079

Bernstein, D.I. (2016). “Public-Private Partnerships: It’s the Right Time.” Business Officer Magazine. Retrieved from

http://www.nacubo.org/Business_Officer_Magazine/Business_Officer_Plus/Bonus_Material/Pub lic-Private_Partnerships_It\%E2\%80\%99s_the_Right_Time.html.

Boehrer, J. (1990-91). Spectators and gladiators: Reconnecting the students with the problem. Teaching excellence - Toward the best in the academy, 2(7), 1-2.

Bridging the gap between higher education and the workplace: A profile of college graduates in Colorado. (2015). Washington, DC: Gallup.

Busteed, B. (2015). Gallup-Purdue index: Great jobs and great lives. Washington, DC: Gallup.

Chickering, A.W., \& Gamson, Z.F. (1991). Seven principles for good practice in undergraduate education. New Directions for Teaching and Learning, 1991(47), 63-64.

http://dx.doi.org/10.1002/tl.37219914708

Colorado Workforce Development Council (20216). The Colorado Talent Pipeline Report. Denver, CO: State of Colorado. Retrieved from https://www.colorado.gov/pacific/sites/default/files/170109_2016_CO_Talent_Pipeline_Report_1.pdf.

Dewey, J. (1933). How we think. Lexington, MA: Heath. 
Doyle, T. (2008). Helping students learn in a learner centered environment: A guide to teaching in higher education. Sterling, VA: Stylus.

Eisenbach, R., Golich, V., \& Curry, R.R. (1998). Classroom assessment across the disciplines. New Directions for Teaching and Learning, 1998(75), 59-66. https://doi.org/10.1002/tl.7506

Ewell, P.T., \& Jones, D.P. (1991). Actions matter: The case for indirect measures in assessing higher education's progress on the national education goals. Journal of General Education, 42(2), 123-148.

Fabry, V., Eisenbach, R., Curry, R.R., \& Golich, V.L. (1997). Thank you for asking: Classroom assessment techniques and students' perceptions of learning. Journal on Excellence in College Teaching, 8(1), 3-21.

Harris, D., \& Bell, C. (1990). Evaluating and assessing for learning (Rev. ed.). New York, NY: Kogan Page.

Jankowski, N.A. (2016). Unpacking relationships: Instruction and student outcomes.

Washington, DC: American Council on Education.

Jankowski, N.A., Ikenberry, S.O., \& Kuh, G.D. (2009). Using evidence of student learning to improve higher education. New York, NY: John Wiley

King, A. (1993). From Sage on the Stage to Guide on the Side. College Teaching, 41(1), 30-35. Retrieved from http://0-www.jstor.org.skyline.ucdenver.edu/stable/27558571. https://doi.org/10.1080/87567555.1993.9926781

Kuh, G.D. (2008) High-impact educational practices: What they are, who has access to them, and why they matter. Washington, DC: Association of American Colleges and Universities.

McDermott, L.C., \& Shaffer, P.S. (1992). Research as a guide for curriculum development: An example from introductory electricity. Part I: Investigation of student understanding. American Journal of Physics, 60(11), 994-1003. https://doi.org/10.1119/1.17003

McKeachie, W.J., Pintrich, P.r., Lin, Y.G., \& Smith, D. (1986). Teaching and learning in the college classroom: A review of the research literature. Ann Arbor, MI: National Center for Research to Improve Postsecondary Teaching and Learning.

Meyers, N.M., \& Nulty, D.D. (2009). How to use (five) curriculum design principles to align authentic learning environments, assessment, students' approaches to thinking and learning outcomes. Assessment \& Evaluation in Higher Education, 34(5), 565-577. https://doi.org/10.1080/02602930802226502

Mezirow, J. (1991). Transformative Dimensions of Adult Learning. San Francisco , CA: JosseyBass. 
MSU Denver Graduate Program Approval Process (2017). Denver, CO: Metropolitan State University of Denver. Retrieved from

https://www.msudenver.edu/media/content/graduatecouncil/gradapprovalprocess\%202\%203\%20 17.pdf.

Newman, L.E., Carpenter, S., Grawe, N., \& Jaret-McKinstry, S. (2014). Creating a culture conducive to integrative learning. Peer Review, 16(4), 14-15.

Pascarella, F.T., \& Terenzini, P.T. How college affects students: Findings and insight from twenty years of research. San Francisco, CA: Jossey-Bass.

Rogers, C.R. (1969). Freedom to Learn. Columbus, OH: Merrill.

Stice, J.E. (1987). Using Kolb’s learning cycle to improve student learning. Engineering Education, 77(5), 291--.

Umbach, P.D. \& Wawrzynski, M.R. (2005). Faculty do matter: The role of college faculty in student learning and engagement Research in Higher Education, 46(153), 153-183. https://doi.org/10.1007/s11162-004-1598-1

What is the “T”? (2014). East Lansing, MI. Retrieved from http://tsummit.org/t.

Wiggins, G., \& McTighe, J. (2005). Understanding by design. Alexandria, VA: Association for Supervision and Curriculum Development. Retrieved from http://www.myilibrary.com?ID=93304.

Zakrajsek, T., \& Doyle, T. (2012). Follow the Research. In Learner-Centered Teaching (pp. 720). Sterling, VA: Stylus. 


\section{Author Information}

Vicki L. Golich is Provost and Vice President of Academic and Student Affairs at Metropolitan State University of Denver; she also oversees Information Technology Services in this role. In 1992, she was selected to be a Pew Faculty Fellow in International Affairs and participated in a two-week workshop at Harvard University's Kennedy School of Government where she learned about actively engaging students in their learning by using case studies. She began her administrative career as the Director of the Faculty Center at California State University San Marcos; in this capacity, she has delivered workshops on case teaching, globalizing the curriculum, and assessment all around the world, and published several articles on the same topics.

*Vicki L. Golich

Academic and Student Affairs

Metropolitan State University of Denver

890 Auraria Parkway

Denver, CO 80209

Email: vgolich@msudenver.edu

Telephone: 303-556-3040

Sandra Haynes is Deputy Provost of Academic and Student Affairs a position that oversees all academic affairs units at Metropolitan State University of Denver. Prior to accepting this position, she served in the Dean's position in the College of Professional Studies at MSU Denver for 13 years. Knowing the importance of maintaining accessible public higher education in an era of shrinking budgets, Haynes has focused her efforts on seeking alternative sources of funding for MSU Denver via public-private-partnerships and interdisciplinary programs that meet community and workforce needs imperative to generating resources, establishing community partnerships, and providing students with excellent teaching and learning experiences.

Sandra Haynes

Academic and Student Affairs

Metropolitan State University of Denver

890 Auraria Parkway

Denver, CO 80209

Email: hayness@msudenver.edu

Telephone: 303-552-7322

Steve Kreidler is the Vice President for Administration at Metropolitan State University of Denver (MSU Denver) a position that oversees all business and operational functions for the university. Previously he served in the same position at the University of Central Oklahoma. His career includes an extensive background in economic and business development and the creation of public private partnerships inside and outside of higher education. MSU Denver has received numerous awards for their activity in partnerships and Kreidler has made multiple presentations at conferences and workshops across the nation on this topic. 


\author{
Steve Kreidler \\ Administration and Finance \\ Metropolitan State University of Denver \\ 890 Auraria Parkway \\ Denver, CO 80209 \\ Email: skreidl1@msudenver.edu \\ Telephone: 303-605-5307 \\ *Corresponding author
}

